\title{
The Assessment of Causes, Levels, and Psycho-Social Impacts of Street Life in Dessie
}

\author{
BY: \\ Moges Gebresellassie \\ May, 2020 \\ Dessie, Ethiopia \\ Wollo University \\ Institution of Teachers' Education and Behavioral Science \\ Department of Psychology
}




\section{ACKNOWLEDGMENT}

I would like to express heartfelt gratitude to my advisor MengeshaBirkie for his positive, reliable professional support, constructive comment, suggestions, and encouragement starting from proposal development up to the completion of this thesis. He spent countless hours trying to make sense out of my work and critique my progress along the way. I glade to appreciate the participants' street children who live in Piyassa, Arada, and Menaharia for their positivity and cooperation during data collection, finally, also give thanks to my family and friends for their idea support and giving morals. 


\section{Contents}

Acknowledgment. 229

ABRIVATIONS 232

Abstract 233

CHAPTER ONE 234

NTRODUCTLON1.1 Background of the study 234

1.2. Statement of the problem 235

1.3 OBJECTIVE OF THE STUDY. 237

13.1 General objective 237

1.3.2. Specific objectives 237

1.4. SCOPE OF THE STUDY 237

1.5 SIGNIFICANCE OF THE STUDY 237

1.6 LIMITATIONS OF THE STUDY 237

1.7 Operational definition of terms 237

CHAPTER TWO. 238

REVIEW OF RELATED LITERATURE 238

2.1 Definition of street children 238

2.2 Problems faced by street children. 238

2.3. Types of street children 239

2.4. Cause of street life 239

2.5 Prevalence of street life. 240

2.6. Psycho-Social problems of street children ................................................................... 240

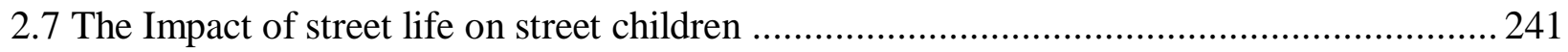

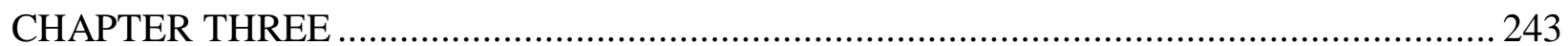

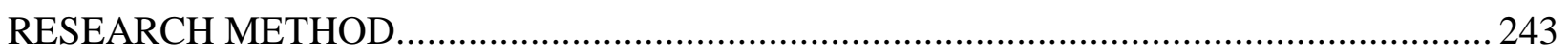

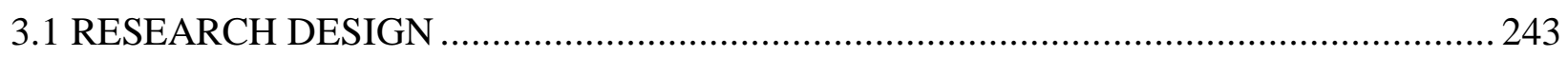

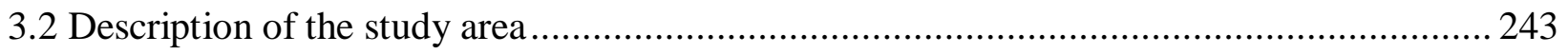

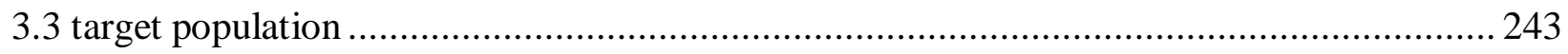

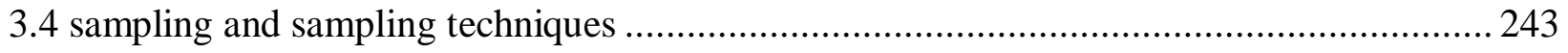

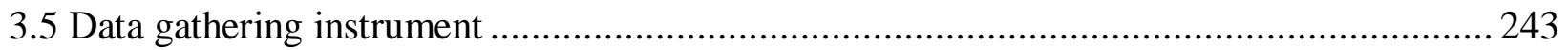

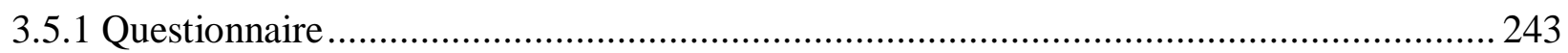

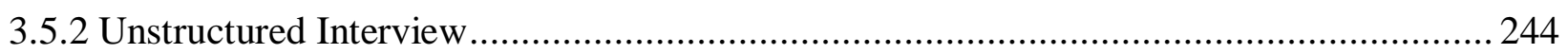

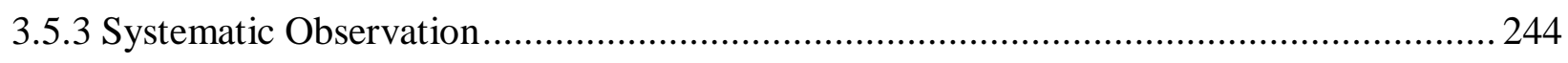

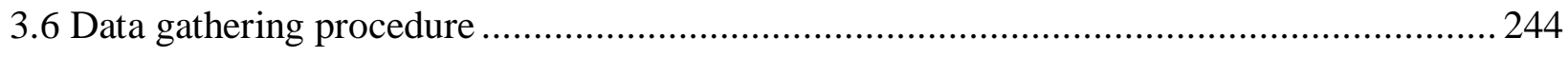




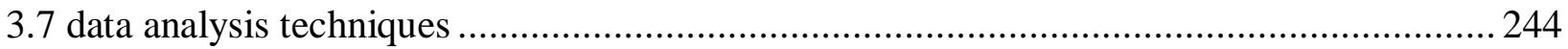

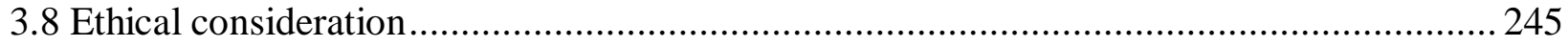

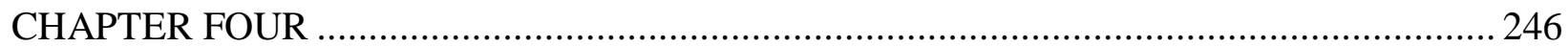

DATA, ANALYSIS, AND INTERPRETATION OF RESULTS ...................................... 246

4.1 Descriptions of Respondents Demographic Characteristics ........................................ 246

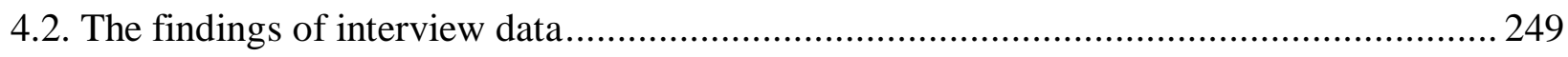

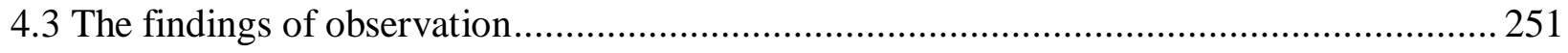

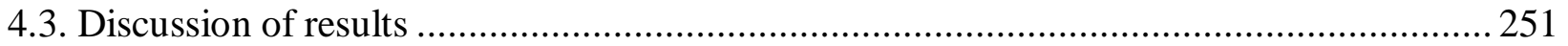

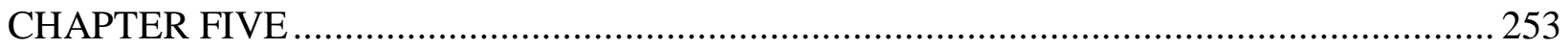

SUMMARY, CONCLUSIONS, AND RECOMMENDATIONS ........................................ 253

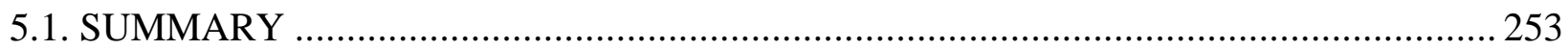

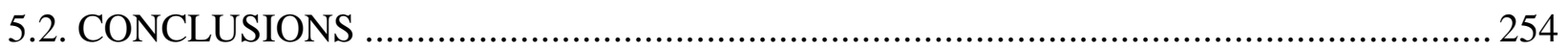

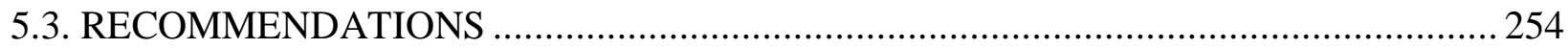

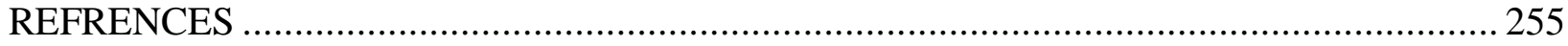

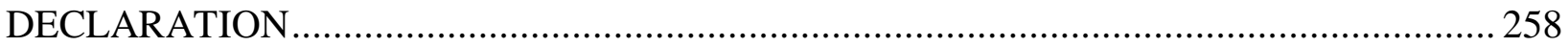

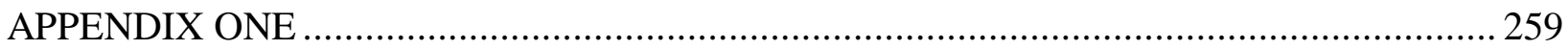




\section{ABRIVATIONS}

HIV/AIDS:HUMAN IMMUNE DEFICIENCY VIRUS /ACQUIRED IMMUNE DEFICIENCY SYNDROME

UNICEF: UNITED NATIONS INTERNATIONAL CHILDREN AND EMERGENCE FUND

UNHRC: UNITED NATION HUMAN RIGHTS COMMISSION

UN: UNITED NATION 


\begin{abstract}
The major purpose of the study was to assess the causes, prevalence, and psychosocial impact of street life in Dessie town in the case of Arada, Piyassa, and Menaharia. The study was conducted in Dessie Town, southern wollo zone of Amara. The data for the study were obtained through questionnaires, interviews, and observation. The data was collected from 70 samples of children live on the street. The researcher has used a Snowball sampling technique. The researcher was employed descriptive design. To analyze the data both qualitative and quantitative research approaches are used. The result of this study shows that strict parenting, quarrel, conflict with parents, work seeking, peer pressure, and mental problems are significant causes for street life. Also, the level of street life in Dessie town was highly increasing. When we see the psychosocial impacts of street life, school dropout, physical abuse, psychological disturbance (feeling of loneness, anxiety, and fear), social exclusion, alcoholism, smoking, chewing chat were the significant psychosocial impacts of street life in Dessie town. Finally, the researcher recommended the correct measures to be taken as well as applying for collaborative work with the government, with nongovernmental organizations and with the local community.
\end{abstract}




\section{CHAPTER ONE \\ INTRODUCTION}

\subsection{Background of the study}

Know days in the globe and specifically, in Africa, there was rapid and wide-ranging of societal, economic, and political changes with both positive and negative consequences. From the negative consequences, one is that a large number of children are found on the street. Street children are becoming worldwide phenomena, the vast majority of these children's work, and live in a large urban area of the developing world (1).

In sub-Saharan Africa, 32 million children are believed to live on the street reports of (2). the existence of the problem of street life in several countries vary in its nature, size, and cause from country to country depending on, the cultural and traditional setting, level of economic growth, institutional interventions, social harmony, and peace(3). According to Child Hope, a Non-Governmental Organization, working with children on the street in Ethiopia, children on the street have become a countrywide epidemic, with over 100,000 children living and/or working on the streets of Ethiopian cities (3). But UNICEF reports that the problem may be more serious, about 600,000 children are found on the streets countrywide and over 100,000 in Addis Ababa(4).

There are different forms of violence against children including abuse, neglect, injury, and maltreatment, exploitation, deprivation and sexual abuse lead children to become on the street (5). Children living on the streets are denied their basic human rights as they have no access to food, shelter, and health care and education are exposed to many forms of abuse and discrimination (6).

UNICEF has defined three types of street children "children on the street" are children who spend most of their time working on the street and market of the cities sailing, or begging funding for themselves but returning on a regular home. Sometimes they are referred to as "market children". The second type is "children off the street" are homeless children who live and sleep on the street in urban areas. The third one is children of street families; children from street families are who are on the street with their families(7).

In African countries, poverty, death of parents, sexual abuse, and violence in the home, neglect, and divorce in the family are some other reasons why street children exist on the street of African countries (8). Several reasons have been suggested for the constant migration of children to the streets. These reasons are family violence, abuse, parental alcoholism, poverty, and parental mortality due to HIV and AIDS (9). In 
developing countries, many children are left alone on account of losing their parents for sexually transmitted diseases such as HIV ADIS, famine, conflict, war, and so forth which finally end up children's life in the streets(10).

A common problem in street children in Africa countries is the abuse of inhalants (9). These inhalants are substances such as tobacco, petrol. Street children end up in jail, car accidents, drowning, or succumbing to sudden death because of these inhalants abuse (9).

Activities that are performed by street children are similar to different countries and include begging, carrying of good for people, small income-generating activities such as shoes shining, car washing, truck pushing, and collecting refuse. Studies of street children in Africa countries have shown that street children are denied to get their necessities. (9).

Children on the street are both spatially and socially oppressed, through multiple forms of social control, marginalization, and powerlessness. As a result, everyday life for a street child can be like living in enemy territory (11).

\subsection{Statement of the problem}

The number of street children and street life is constantly increasing in the world today. This is a kind of situation, which needs close attention and investigation. Know a day's children around the world are living at risk of exploitation, abuse, and discrimination. Children, those who face human right abuses, needs protection to increase their physical, mental, spiritual, moral, and social development.

Children on the street are a global phenomenon, African, South American, and Asia countries aremore affected by the problem (12). However, its size, nature, and causes vary from continent to continent, country to country, society to society, and even from one child to the other depending on the cultural and traditional setting, level of economic development, institutional interventions, and the level of social harmony and peace (13). The factors that lead children to the street and childhood marginalization in Ethiopia are as complex as the socio-economic, political, and cultural situations (14).

Children and adolescents can be especially vulnerable to a wide range of sexual and reproductive health. Girls can be particularly vulnerable, as they have sexual relationships at a much earlier age than boys; and this leading them to unwanted teenage pregnancies, sexually transmitted diseases, other physical or psychological problems, simultaneously all this problem create problematic social relation. Also, many 
children's boys and girls become orphans by HIV/AIDS, rendering them dependent on others many ways; they lack income, access to education, food, housing, and vulnerable themselves to sexual health problems including sexual abuse and exploitation (15).

Street children through the world are particularly at risk for HIV/AIDS infection and other sexually transmitted diseases for several reasons; the need to perform survival sex (prostitution) greater freedom to experience sex, lack of adult protection, and adults seek younger sex partner who is assumed to be free from HIV/AIDS. Moreover, the children have little power to negotiate on the use of condoms and violence of rough sex practice, lack of knowledge and access to health service is also a contributing factor (16).

The studies carried out on the street children in different areas of the city, Addis Ababa was mainly concentrated on exploring the life experience, the perceptions of the community, and the role of the institution, the problems, and their survival strategies of children being on the street. Thus, a detailed study on the factors leading children to the street, their challenges, and coping mechanism are needed in the Piassa area, Arada Sub-City of Addis Ababa. No more focus is given to other regional cities like Bahirdar, Mekele, Hawassaand Dessie, etc.

This research is, therefore, conducted to fill the research gap by investigating the factors leading to children on the street, levels, and psychosocial impacts of street life in Dessie city. Along with this, the life of the children on the street the researcher perceived in a day to day life in the study area caught the attention to do this research. The Center of attention in this study is children on the street between the ages of 9 to 18 .

When the researcher came to the specific area in Dessie town, many street children live on the street. Among these children, most of them are live around the street of circle Piyassa, Arada, and Menehariaya. The researchers were focus to assess the causes of the levels and psychosocial impacts of street children in the above-listed areas.

Thus this study raised the following leading research questions to be answered:

1. What are the causes of street life in Dessie town?

2. What looks like the level of street life in Dessie town?

3. What are the psychosocial impacts of street life in Dessie town? 


\subsection{OBJECTIVE OF THE STUDY}

\subsection{General objective}

The general objective of this study was to assess causes, levels, and psychosocial impacts of street life, in Ethiopia Amara region Dessie Town specifically at Piyassa, Arada, and Menaharia areas.

\subsubsection{Specific objectives}

The specific objectives of this study were

- To identify the cause of street life in the study area.

- To describe the level of street life in the study area.

- To assess the psychosocial impact of street life in the study area

\subsection{SCOPE OF THE STUDY}

In this study, the researcher was trying to assess the cause, level, and psychosocial impacts of street life in Dessie Town specifically Piyassa, Arada, and Menaharia areas in the year 2019.

\subsection{SIGNIFICANCE OF THE STUDY}

This study gives information about the causes, level, and psychosocial impacts of street life. It can provide the knowledge and necessary information concerning the street children in Dessie town. It can help the concerned bodies to identify and understand the causes and the level of street life. It also shows the direction of how to prevent, intervene, and promote the psychosocial wellbeing of street children in particular and the community in general.

\subsection{LIMITATIONS OF THE STUDY}

The researcher only selects 70 participants specifically at Arada, Piyassa, and Menehariya areas the other areas are not covered in this study this may hinder the reliability of the research result. During data gathering, some participants were not willing to respond to the interview and fill the questionnaire so I leave them and search for the other. This Situation makes the data collection difficult to get the appropriate data. On the other hand, there was a problem of translating the data collected into the English language since street children use some jargon Amharic words.

\subsection{Operational definition of terms}

Child: Anyone who claims to be or can be, under physical characteristics, believed to be under the age of 18 years.

Streetlife - a condition of having no home/especially the state of living in the street.

Street children- are homeless children who live on the street of a city, town, or village.

Psychosocial problem- psychological and social challenges that face the children as a result of street life. 


\section{CHAPTER TWO \\ REVIEW OF RELATED LITERATURE}

\subsection{Definition of street children}

Children on the street UNICEF defined as any girl or boy for whom the street (in the widest sense of the world, including unoccupied dwellings, wasteland, etc.) has become his or her habitual abode and/or source of livelihood, and who is inadequately protected, supervised, or directed by responsible adults (17).

Any girl or boy who has not reached adulthood, for whom the street (in the broadest sense of the word, including unoccupied dwellings, wasteland, etc.) has become her or his habitual abode and/or sources of livelihood, and who is inadequately protected, supervised or directed by responsible adults(18).

There are two groups of street children. The first group is 'Children of the street', which refers to children who are homeless, and streets in urban areas are their source of livelihood, where they sleep and live. The second group is 'Children on the street', who work and live on the streets in the daytime but return back home at night where they sleep, although some of them sleep occasionally on the streets (19). Nevertheless, there is no clear distinction between the two groups as they often differ from their common definition: some 'children of the street' may still have links with their families and some 'children on the street' often sleep on the street (20).

\subsection{Problems faced by street children}

Street children often lack the support of their families. Hence from a very young age, they support themselves by working to earn an income. This keeps them away from regular and structured education. They live in unsanitary conditions, which results in them suffering from chronic health problems like asthma and dysentery. Being on the street also gives them easy access to drugs, alcohol, and tobacco, hence substance abuse is also a major problem that such children are prone to. Although underlying and immediate causes of the street children phenomenon may differ, therange of problems that children suffer once in the street present some similarities across regions:poor education status, low self-esteem, and emotional disorders, violence and exploitation bypeers and adults, early and unwanted pregnancies, sexually transmitted diseases and HIV/AIDS, and drug abuse. In Latin and Central America, a very high number of street children are victimsof brutality by police and other adults(21). 
Street children are often more vulnerable to sexual and reproductive health problems. They are often prone to, sexually transmitted diseases, HIV/AIDS, unwanted pregnancies, and unsafe abortions. It has been seen that sexual and reproductive health problems affect both girls and boys. Street children have several psychological problems, "due to insecurity and continued anxiety, violation, maladjusted behavior throughout their lives"(22).

\subsection{Types of street children}

A typology based classification of the children in the street life and family contact. The term street children in Ethiopia are a collective level. There are three types of street children(4).

The children who are both economically and socially engage in street life. These children have little or no contact with relatives, are homeless, and fully lack parental, emotional, and psychological support they often move from place to place living in a shelter and abundant buildings.

The children who maintain good family ties and often return home in the evening. These children spend most day some night working and socializing on the street because of poverty, overcrowding, sexual or physical abuse at home of different categories this is the most innumerous.

The children whose parents are also exposed to street life. They may be displaced due to poverty, war, or natural disaster. In this cause, often work on the street with other members of their families.

\subsection{Cause of street life}

Studies showed that in many developing countries the exposure of children for a risk "a natural outcome of reflection of the socio-economic factors. Rural-urban migration, incipient revolution, and other social unrest, whereas in developing countries the exposure of children for danger is related to moral abandonment(23).

The report of the UN on violence against children also indicates that children who have been sexually abused or extremely neglected, or who have experienced violence at home, may run away into a street life which exposes them to the risk of sexual abuse or exploitation (24). 
Children feel that living on the streets is better than coping with problems in their homes. These problems can include conflicts with parents, physical or sexual abuse, or some children are forced to leave home by their families because; the family does not approve a child's behavior or its consequences. Pregnancy, homosexuality, or substance use (25).

Poverty, natural disasters, war and violence, family disintegration, HIV/AIDS are the major reason why children live and work on the streets. They are particularly vulnerable to exploitation and abuse and have little opportunity to claim their rights (26).

Family disorganization or disintegration, parental death, unfavorable home environment, absence of adult supervision and parental pressure to start work, and rural-urban migration, Which negatively affect the stability of families is another' force causing street life to increase at an alarming rate (27).

Additionally, risks are factors that expose children to circumstances associated with high incidences. Those factors include personal, school-related, peer, family, and community impacts that increase the possibility of behavior such as leaving school permanently or engaging in delinquent behavior patterns (28).

\subsection{Prevalence of street life}

There are no accurate estimates of the number of children on the street worldwide, and estimates often vary from one source to another. There are an estimated 150 million in the world, and numbers are increasing across the African continent. By 1992, the Organization of African Union estimated that Africa had about 16 million children on the street and 32 million by the year 2000 (29). UNICEF report indicates that, in sub-Saharan Africa, 32 million children are believed to live on the street(2).

\subsection{Psycho-Social problems of street children}

Children and adolescents can be especially vulnerable to a wide range of sexual and reproductive health Problems include HIV/AIDS. Girls can be particularly vulnerable, as they have sexual relations at a much earlier age than boys. And this leading them to unwanted teenage pregnancies sexually transmitted diseases including HIV/AIDS and other physical or psychological problems and simultaneously all this problem create problematic social relation. And also many children's boys and girls become orphans by HIV/AIDS, rendering them dependent on others many ways; they lack income, access to education, food, housing, and vulnerable themselves to sexual health problems including sexual abuse and exploitation.In addition to this, their rights are violated as they face the risks of violence, abuse and exploitation, health hazards, stigma and 
discrimination, and psychological problems related to stress, anxiety, and depression, it also their selfesteem is challenged by the experience of humiliation, guilt, and helplessness(30).

Once on the streets, the children get absorbed in the big bad world of the urban streets, they get introduced to substance use, Start getting engaged in diligent behaviors, and get pushed by their peers, or experience pressure from the gangs to get involved in criminal activities. As a result of this, children on the street are seen as a problem, and a threat to society instead of reviewed as children with a problem who need help from society. They are also perceived as transgressors because they often use drugs, commit robbery, and make noise (31).

\subsection{The Impact of street life on street children}

There are many challenges that street childrenare encountering in the streets. Some of the challenges that street children face in the streets include malnutrition or difficulty to access basic nutrition, susceptible to cuts and wounds due to lack of shoes and protective clothes, injuries and physical pain due to work and walking long distances. The phenomenon of street children has long existed in many regions. Today it is also making unexpected appearances where it never existed before. What does seem clear, however, is that street children are the extreme manifestation of deteriorating social capital and social exclusion. While theimmediate factors responsible for their condition are unique for each child, they generallyrepresent some combination of low family income, lack of housing, failure in school, familyneglect and abuse, armed conflicts, natural disasters and epidemics.Exposure to drugs, violence, and abuse by other street children, the general public, and law enforcement officials that street children endure in the streets may make them feel nervous, scared, angry, or confused (21)

The negative impacts of street life include the following. Extreme deprivation and social exclusion of street children which create opportunities for engaging in crime. Street children perceive themselves as discriminated against and hated by the members of society. Street children are stigmatized because they do not have the power to demand attention from the public and private agencies. Street children are also subject to social, physical, psychological, and sexual abuse. Some survival strategies of street children include menial income-generating activities to survive. Some of these activities include helping motorists at the car park, washing cars, begging for money, selling fruit and vegetables, and prostitution, carrying personal belongings of passengers as well as collecting scraps from garbage and dumps and selling them (32). 
The money that they earn from these activities is used to purchase food, cigarettes, local beverages, and other necessities. Other unlawful activities comprise theft, robbery, assault, prostitution, petty offenses, fighting among them, littering in public places, gambling, causing disturbances, and deliberately damaging vehicles of people who decline their offer of parking assistance and car washing. These unlawful and dangerous activities that street children engage themselves in may lead to serious injury or even death (9).

The relationship of street children with people around them contributes to their means of survival. Street children's relationships can either be intergenerational or intragenerational. Intergenerational relations refer to the state whereby street children still maintain their relationships with parents, particularly mothers, especially the "children-on-the-street". These street children usually visit their homes to change clothes and eat; nevertheless, they stay only for a short period(33).

Intragenerational relations refer to a situation where street children take care of their siblings on the streets, especially children of the street who stay with their families. In this case, the older siblings protect their young siblings in return for the younger siblings doing some work for them. They also form friendships and alliances with adults who survive on the streets as a way of adapting to street life (33).

Street children's coping mechanisms also include changing their sleeping locations to hide from their aggressors, sometimes even hide in the underground, creating their affiliated community where they could live in an atmosphere of love and a sense of family hood (34). 


\section{CHAPTER THREE \\ RESEARCH METHOD}

\subsection{RESEARCH DESIGN}

In this study, the descriptive research design was used. The researcher was using both quantitative and qualitative methods of data analysis.

\subsection{Description of the Study Area}

Dessie has located approximately $401 \mathrm{~km}$ from Addis Ababa. Based on the census conducted by the central statistical agency of Ethiopia (35), Dessie town has a total population of 151,094 out of this 72,891 are males and 78, 203 are females.

\subsection{Target Population}

The target population of this study was only street children in Dessie Town which lives in kebeles of Piyassa, Arada, and Menaharia.

\subsection{Sampling and Sampling Techniques}

The researchers used a non-probability sampling technique called the snowball sampling technique. The reason Snowball sampling is a little known about the population under the study. Acquiring one subject then asking them to refer to another subject so for theirs. This sampling technique helps to differentiate street children from that of non-street children because the researcher selects the participant based on the information which is given by the prior respondents. To conduct this research 70 street children were selected as participants of this study.

\subsection{Data Gathering Instrument}

To get reliable and accurate data the researcher has employed a questionnaire, unstructured interview, and systematic observation.

\subsubsection{Questionnaire}

The questionnaire was the main data collection instrument of this study. It contained close-ended and open-ended questions. The question was constructed according to the research problem. The questionnaire was prepared by the researchers and there were 23 questionnaires, then it was distributed to the study participants. The research questions were cheeked their reliability of (0.76) during the times of pilot study. 
During data collection, the concept of the questionnaire was made clear by the researchers to get relevant information from the participants.

\subsubsection{Unstructured Interview}

The unstructured interview was also conducted to get reliable information about the cause of street life, level, and psychosocial condition of the street children. During the interview process, the researcher uses sound recording tools and some notes taken while talking with respondents. The unstructured Interview questions which need further interpretation are interpreted by the researcher during the interview process until it becomes clear for the participant of the study and until the clear explanations were given by the participant.

\subsubsection{Systematic Observation}

Observation can give as large amounts of rich, interesting, and valid data. It is an important tool not only to collect real and observable information about the activities and behaviors (emotions and feelings) of the informants under investigation but also it is important to check the validity of the information produced in other data collection tools (36). Moreover, systematic observation is appropriate for collecting data on naturally occurring behaviors in their usual contexts. Observation as a method used the researcher as the direct witnessing of ongoing social life as the preferable foundation of research (37). In this research, a systematic observation was used to check psychosocial challenges faced by children while living on the street. The observation has been held at different places by walking on the street, sitting atcafe, restaurants.

\subsection{Data Gathering Procedure}

The researcher followed the necessary formal process of data collection, the researchers received a formal paper from the department of psychology then started gathering information about the cause, level, and psychosocial impacts of street life. To gather data from the respondents the researcher was introducing them for the participants and ask their willingness to participate in the study and lastly, the questionnaire was distributed and the interview questions are interviewed face to face manner.

\subsection{Data Analysis Techniques}

After collecting the data through questionnaires, interviews, and, observation the researcher was analyzing through qualitative and qualitative methods, the quantitative was analyzed by using percentage, frequency, mean, and t-test. In addition to this, the qualitative data collected through interviews and observation was analyzed by using thematic interpretation and narration. 


\subsection{Ethical Consideration}

The first ethical principle the researcher show for participants were asking their permission before the study was started and get their consent. Due to this the researcher first informed about the purpose of the research, its procedure, benefit, and as they have the right to withdraw at any time when they want to stop. So they may not be enforced to participate in the research and within this principle, I saw anonymity and confidentiality about participants. 


\section{CHAPTER FOUR}

\section{DATA, ANALYSIS, AND INTERPRETATION OF RESULTS}

The main objective of this research was to investigate the cause, level, and psychosocial impact of street life among street children in Dessie specifically at Piyasaa, Arada, and Menaharia. The chapter embraces four themes based on the research questions outlined to be answered in the event of the study. The first section tells about the demographic variables of the participants. The second section involves the level of triggering factors for street life analyzed by a one-sample t-test. The third part indicates the psychosocial impact of street life. The last part, part four includes the impact of street life on the psychosocial well-being of street children.

\subsection{Descriptions of Respondents Demographic Characteristics}

This section presents the response rate and demographic characteristics of the sample respondents. Accordingly, a total of 60 copies of a questionnaire were distributed, and 60 usable questionnaires were returned, providing a response rate of $100 \%$. Respondents' demographic characteristics (respective of age, sex, educational level, religion, and place of birth) which were included in the present study are summarized in Table 1 below.

\begin{tabular}{|c|c|c|c|c|}
\hline No. & variable & Category & frequency & Percent \\
\hline \multirow{3}{*}{1} & \multirow[t]{3}{*}{ Age } & below 10 years & 8 & 13.33 \\
\hline & & $11-15$ years & 30 & 50.0 \\
\hline & & $16-20$ years & 22 & 36.66 \\
\hline \multirow[t]{2}{*}{2} & \multirow[t]{2}{*}{$\operatorname{sex}$} & Male & 43 & 71.67 \\
\hline & & Female & 17 & 28.33 \\
\hline \multirow[t]{4}{*}{3} & \multirow{4}{*}{$\begin{array}{c}\text { educational } \\
\text { status }\end{array}$} & $1-4$ & 26 & 43.33 \\
\hline & & $5-8$ & 14 & 23.33 \\
\hline & & $9-12$ & 8 & 13.33 \\
\hline & & No formal education Can read and write & 12 & 20 \\
\hline \multirow[t]{5}{*}{4} & \multirow[t]{5}{*}{ Religion } & Orthodox & 37 & 61.67 \\
\hline & & Catholic & 0 & 0 \\
\hline & & Protestant & 0 & 0 \\
\hline & & Muslim & 23 & 38.33 \\
\hline & & Others & 0 & 0 \\
\hline \multirow[t]{2}{*}{5} & \multirow[t]{2}{*}{ Place of birth } & Rural & 43 & 71.67 \\
\hline & & Urban & 17 & 28.33 \\
\hline
\end{tabular}

Table1. Summary of respondents by their age, educational level, religion, and place of birth 
As it is indicated in the table above, $8(13.33 \%)$ of the participants were under the age of 10 years. Participants with the age range from 11-15 years are $30(50 \%)$. The rest $22(36.66 \%)$ of the participants were are under the age range of 16-20.

Concerning participant's sex, $(71.67 \%)$ were male and the rest $(38.33 \%)$ were females. In line with the participant's educational status, (43.33\%) are under 4-grade levels. the educational status of 5-8 grade levels are $(23.33 \%)$, the educational status of 5-8 grade levels are (13.33\%) and children with no educational levels but can read-write by their efforts are $20 \%$. Regarding the participants' religion, $(61.67 \%)$ were Orthodox and the rest $(38.33 \%)$ were Muslim. (71.67\%) were from rural and the other $(28.3 \%)$ were from urban areas.

Table 2 One sample t-test Summary of respondents on causes of street life

\begin{tabular}{|c|c|c|c|c|c|c|}
\hline \multirow{2}{*}{ Causes } & \multicolumn{7}{|c|}{ Test value= 3 } \\
\cline { 2 - 7 } & $\mathbf{N}$ & Mean & Std. Deviation & t-value & Df & $\begin{array}{c}\text { Sig. (2 } \\
\text { tailed) }\end{array}$ \\
\hline Strict parenting & 60 & 3.78 & 1.50808 & -1.969 & 59 & .054 \\
\hline Quarrel with parents & 60 & 3.35 & 1.57308 & .000 & 59 & 1.000 \\
\hline feeding & 60 & 2.67 & 1.51630 & -1.788 & 59 & .079 \\
\hline economy & 60 & 2.75 & 1.49906 & -2.153 & 59 & .035 \\
\hline Low school performance & 60 & 2.44 & 1.30308 & -5.251 & 59 & .000 \\
\hline seeking work & 60 & 3.58 & 1.35911 & 2.755 & 59 & .008 \\
\hline Peer pressure & 60 & 3.28 & 1.38352 & .746 & 59 & .458 \\
\hline orphaned & 60 & 2.68 & 1.37615 & -5.253 & 59 & .001 \\
\hline
\end{tabular}

Significant at $P<0.05$

As indicated in table 2, the mean score of the participants on feeding (2.67), economy (2.75) low school performance (2.44), and Orphaned (2.68) as a cause for street life was found below the expected mean, 3. This indicated that the impact of these variables for street life was below average the impact as such not significant.

The other possible cause for street life is strict parenting (3.78), quarrel (3.35), seeking work (3.58) and peer pressure (3.28) are above the mean and it was found significant factor to engage in street life. 
Table 3. One sample t-test Summary of respondents' response on the level of prevalence

\begin{tabular}{|c|c|c|c|c|c|c|}
\hline \multirow[t]{2}{*}{ The level prevalence } & \multirow[b]{2}{*}{$\mathbf{N}$} & \multirow[b]{2}{*}{ mean } & \multirow[b]{2}{*}{ Std. Deviation } & \multirow[b]{2}{*}{ t-value } & \multirow[b]{2}{*}{ Df } & \multirow[b]{2}{*}{ Sig. (2 tailed) } \\
\hline & & & & & & \\
\hline $\begin{array}{c}\text { After I have joined street life, many } \\
\text { other children are also include. }\end{array}$ & 60 & 3.7133 & 1.20451 & 5.145 & 59 & .001 \\
\hline $\begin{array}{l}\text { Interventions are made to minimize the } \\
\text { rate of street life. }\end{array}$ & 60 & 1.6526 & 1.12433 & -7.464 & 59 & .001 \\
\hline $\begin{array}{l}\text { Awareness creation is implemented to } \\
\text { combat causes of street life. }\end{array}$ & 60 & 1.8462 & 1.13633 & -7.612 & 59 & .001 \\
\hline
\end{tabular}

Significant at $\boldsymbol{P}<0.05$

As indicated in table 3, the mean score of the participants on the prevalence of street life who answer the question after I have joined street life, many other children also come to the street was found to be 3.75 which was significantly above the expected mean, 3. Likewise, the participants' mean score about Interventions made to minimize the rate of street life mean value was (1.65) and for the question, Awareness creation is implemented to combat causes of street life was found to be mean value was (1.84) Which are below the expected mean. This indicated that there is no intervention and awareness creation to minimize the rare of street life. So this shows that the prevalence of street life in Dessie town is increasing.

Table 4. Onesample t-test Summary of respondents' psychosocial Impact of street life.

\begin{tabular}{|c|c|c|c|c|c|c|}
\hline \multirow{2}{*}{ Impact } & \multicolumn{7}{|l|}{} \\
\cline { 2 - 7 } & $\mathbf{N}$ & mean & Std. Deviation & t-value & Df & Sig. (2 tailed) \\
\hline Sexual abuse & 60 & 3.2735 & 1.07619 & -8.397 & 59 & .000 \\
\hline Physical abuse & 60 & 3.4341 & 1.71105 & 1.056 & 59 & .295 \\
\hline Drug abuse & 60 & 3.8370 & 1.69446 & -.457 & 59 & .649 \\
\hline school dropout & 60 & 4.5426 & .97772 & 11.091 & 59 & .000 \\
\hline Physical Injury & 60 & 2.7530 & 1.45079 & -.623 & 59 & .536 \\
\hline Psychological disturbance & 60 & 3.3412 & 1.29700 & 1.493 & 59 & .141 \\
\hline Social exclusion & 60 & 3.2620 & 1.29928 & 1.192 & 59 & .238 \\
\hline
\end{tabular}

Significant at $\boldsymbol{P}<0.05$ 
As indicated in table 4, the mean score of the participants on sexual abuse as an impact for street life was found to be (3.27) which was significantly above the expected mean, 3. Likewise, participants' mean score on the physical abuse as an impact of street life was found to be (3.43) which was above the expected mean. Drug abuse as an impact on street life was found to be (3.84) which was above the expected mean. When we see school dropout as the impact of street life it was found above the expected mean (4.54) which is highly significant. Psychological disturbance found to be (3.34) above the expected mean which is significant. Social exclusion was found to be (3.26) which was above the expected mean. The only variable Physical injury; the mean score is (2.75) which was below the mean and not significant.

\subsection{The findings of interview data}

From 70 participants, 10 samples were selected and interviewed. The samples were selected because they are younger than the others and have a leading role in the street and have a big influence on the group. The researcher believes that they may explain well the questions they are asked.

The researcher asked the following questions for the selected 10 participants. But during the process of the interview; when the researcher thinks asking additional questions is necessary the researcher asks more additional questions to make clear the answer of the participant.

1. What are the causes of many children to be engaged in street life? Elaborate?

2. How do you express the level of street life in your living areas? How does it look like? Is it decrease or increase?

3. What are the psychosocial impacts of street life? What looks like the challenges? Would you explain it, please?

For the question one, the respondents were said, there are different causes which can lead to street life some of them are punishment by parents and unable negotiate with parents, workload, low school performance, unemployment, peer pressure, and because of, mental illness, leads into street life.

Informants show that many causes lead to street life. Problems occurred in the children family was the major cause that forced to leave their home. One of the informants, who is living on the street due to the reason for her families are forced to her to engage in marriage than education without her consent and permission? 
She noted as follows:

My parents are poor economically. They are unable to educate me. They want me to marry our neighbors soon which were strong economically. But I am not interested in that marriage. I tolled for my parents that I am not interested to have marriage; I prefer to continue my education. My father refuses my idea and he said that "you have no mandate to decide on such an issue! I am the leader of this family and I am the leader of this house! So you should accept my decision! You should marry our neighbors soon!" After that time I leave my parents' home and I come to Dessie and I start the street life.

As one of the interviewed participants, he joined street life because of that: "In our family, I am the younger of the other children. My father always gives me difficult works and if I am not accomplishing a work he punishes me. One day as usual he orders me to perform a job and I can't accomplish that work. I know that what will follow if I do not accomplish that work; that is punishment. I can't tolerate that difficult physical punishment. I decided to leave home and go to urban areas. The reason for my life is my father's severe physical punishment".

For the second question, respondents said that the prevalence of street life in their living areas in the case of Piyassa, Arada, and Menaharia increasing and other new children are becoming in the street. One of the four participants stated that:

"I have been in the street for the last 5 years and when I come here I have only 2 friends at that time. But nowadays I have more than 8 friends all of them are newcomers from home. I know many other children come to the Street from different parts of the region."

For the third question, respondents said that the impact of street life is so many and it has a great influence on their day to day activities in the street. The impacts include; there is a school dropout, addiction, physical abuse, females are abused sexually, lack of medication, psychological disturbance like the feeling of loneness and fear, they are observed by others as criminals, and they are excluded from the society.

One of the interviewed participants said that: "when I was with my family I am not smoking, I am not chewing chat, and I am not drinking but know I do all of the above. I always worry with myself, what will be my future fate and destiny? Who will help me if I am ill, no one? Such questions always disturb me. Society has a negative attitude to street life they considered all of us were thief but that is not true; some good boys didn't do such things". 


\subsection{The findings of observation}

Based on my observation a large number of children are on the street. They are found mostly the places where children on the street hang out in Dessie are piyassa, road, Arada and Menehariya, areas. I observe that children on the street turn to many different activities to survive or do many things to maintain their life on the streets. Their activities include begging, stealing, and carrying goods/luggage. They also, engaged in small business activities such as (sukbederetea) petty trader (peddler), shoe shining, selling lottery, works with taxi drivers and some of them do nothing but they share food with their friends because no one eats alone.

Between Piyassa and Menehariya during the night times, I observe many under age Commercial sex workers to generate income. Many children also sleep on the street. I count more than 8 street children's sleep together on the sides of the road. Some of them also group and burn rubbish papers to get heat to relapse from the cold air condition.

During the study, the informants revealed the psychoactive drugs that they often use commonly which include benzene sniffing, smoking cigarettes, chewing "chat

\subsection{Discussion of results}

Concerning the first research question on the cause of street life, this research funding reveals that strict parenting, quarrel, conflict with parents, work seeking, peer pressure, and mental problems are the significant causes for street life. The researches of (10)showed that family breakdown, urban poverty, and migration were crucial factors that drive children to the street. The finding is also similar to (1)Children run away to the streets to avoid abusive punishments in the family. The other reasons for street life are, limited opportunities for education and employment, child abuse and neglect, parental conflict, and poor parenting, (38).

However, other researchers somehow argued differently. UNICEF (4) (1991. 1992, and 1993) stated that the cause of street life in Ethiopia as a result of, war, drought, and engagement in criminal activities. The difference may be due to; at the times of 1991. 1992, and 1993 in the Ethiopian calendar there was war and it may be the cause for street life. And in other parts of the world, for example in studies show that the cause of street life is a natural disaster and growing urbanization, the difference is due to the study area difference(39). 
When we see the level of street life in Dessie city, the findings show that the prevalence of street life becomes highly increasing. Intervention and corrective measures were not taken by the government as well as other non-governmental organizations. Researches also support it for example (10) says that the number of children on the street is increasing and the children are vulnerable to various problems from time to time. Few NGOs are working exclusively with children on the street in Ethiopia, aimed to enable children on the street to return to life in a caring and stable family environment, either with their own family, a foster family or by living independently in the community. Also, they provided them the educational, social, and incomegenerating activities they require to overcome the economic and socio-cultural factors that pull and push children to the street, reintegrate into society and family life, and to embrace the future. However, still, the situation is uncontrolled (21).

Concerning with the psychosocial impacts of street life, this study The impacts include; there is a school dropout, addiction, physical abuse, females are abused sexually, lack of medication, psychological disturbance like the feeling of loneness and fear, According to (40)girls face extremely harsh conditions including sexual abuse by adults, rape, unwanted pregnancy, and early motherhood - at times as early as 12 years old. Findings of (15) Female children on the street were also found to engage in high-risk behaviors, including unsafe sex, which increased their risk of contracting HIV/AIDS and other sexually transmitted infections. (41)also found that street children are characterized by substance abuse, petty crime, alcoholism, smoking, drugs, chewing chat, and the like. All the above researches findings are consistent with this study. 


\section{CHAPTER FIVE \\ SUMMARY, CONCLUSIONS, AND RECOMMENDATIONS}

\subsection{SUMMARY}

The main purpose of this research was to investigate the causes, Levels, and psychosocial impact of street life among street children in Arada, piyassa, and Menaharia in Dessie city administration. In doing so, the researchers of this study have outlined the following leading research questions.

1. What are the causes of street life in Dessie town?

2. What looks like the level of street life in Dessie town?

3. What are the psychosocial impacts of street life in Dessie town?

To answer these leading questions of the research, the researchers mainly used descriptive research design. The collected data was analyzed through qualitative and quantitative research approach. To generate reliable and valid data, 70 participants are selected by using a snowball sampling technique. Of these, 10 participants were interviewed. To collect the appropriate and the relevant data questionnaire tools are prepared, 7 items that measure causes of street life, 3 items to measure the level of street life, and 8 items that measure the psychosocial impact of street life were used. Apart from this, 3 unstructured interview items were used to generate qualitative data.

After the data has been collected, it was checked, edited, and coded. Then the quantitative data were analyzed by using a one-sample t-test. The qualitative data were analyzed by using narratives and interpretive analysis.

The findings of this research revealed that strict parenting, quarrel, conflict with parents, work seeking, peer pressure, and mental problems are significant causes for street life. The level of street life in Dessie city is becoming highly increasing. The number of children on the street was increasing and the children are vulnerable to various problems from time to time.

Moreover, the findings indicated that school dropout, physical abuse, psychological disturbance (feeling of loneness, anxiety, and fear), social exclusion, alcoholism, smoking, chewing chat were the significant psychosocial impacts of street life. 


\subsection{CONCLUSIONS}

The study findings show that strict parenting, quarrel, conflict with parents, work seeking, peer pressure, and mental problems are significant causes for street life. Also, the level of street life in the study area is increasing. When we see the psychosocial impacts of street life, school dropout, physical abuse, psychological disturbance (feeling of loneness, anxiety, and fear), social exclusion, alcoholism, smoking, chewing chat were the significant psychosocial impacts of street life in Dessie town.

\subsection{RECOMMENDATIONS}

In this paper, an attempt has been made to assess the causes, the level, and psychosocial impacts of street children' in the study area. Based on the finding and conclusion, the following recommendations are forwarded which can be implemented in the short and long term plans.

Protection is needed for children from being abused physically.

Facilitate skill training and income-generating scheme and create job .opportunities for street children by different NGOs and governmental organizations.

Educating the community about the danger of street life and the problem of street life to bring behavioral and attitudinal changes. This could achieve much faster if cooperation among different organizations exists.

Provide emotional support and counseling service for street children to cope with psychological disturbance.

Facilitating school programs for street children.

Helping children to cope with peer pressure.

Providing rehabilitation service for drug-addicted street children.

Bringing legal action against individuals who commit violence against street children.

Ensuring that employment and educational services are fully accessible to street children. 


\section{REFRENCES}

[1]. Kopoka PA, editor. The problem of street children in Africa: An ignored tragedy. international conference on Street Children's Health in East Africa, Dar-es-salaam, Tanzania, April; 2000.

[2]. UNICEF. The state of the world's children 2006: excluded and invisible: Unicef; 2005.

[3]. Berhe K. Life in the streets of Adama: the situation of street children in a fast growing Ethiopian town. Addis Ababa University. 2008.

[4]. UNICEF. Children Working on the Streets of Ethiopia, A UNICEF Report. 2000.

[5]. Gebre A. Migration patterns of children exposed to sexual exploitation in selected zones of Ethiopia. Journal of Children's Services. 2012.

[6]. Kauffman Z, Bunkers K. Retrak report: De-institutionalization of street children in Addis Ababa, Ethiopia. Manchester, Retrak; 2012.

[7]. Mehta D. Street Children and Gangs in African Cities: Guidelines for Local Authorities. UMP Working Paper Series 18, 2000.

[8]. Orme J, Seipel MM. Survival strategies of street children in Ghana: A qualitative study. International social work. 2007;50(4):489-99.

[9]. Mashicolo GN. Understanding streetism from the street children's perspective: a qualitative approach: North-West University (South Africa), Vaal Triangle Campus; 2016.

[10]. Endris S, Sitota G. Causes and Consequences of Streetism among Street Children in Harar City, Ethiopia. International Journal of Education and Literacy Studies. 2019;7(2):94-9.

[11]. Hutchison R. Encyclopedia of urban studies: Sage; 2010.

[12]. Dryjanska L. Thematic review: Negotiating identities of street children. A short reflection piece. Papers on Social Representations. 2014;23(1):3.1-3.27.

[13]. Kibrom B. Life in the streets of Adama: The situation of street children in a fast growing Ethiopian town. Unpublished MA thesis), Addis Ababa University. 2008.

[14]. Tatek A. 'Sikalla': the survival strategies of Ethiopian chiled beggers. s Ege, H aspen, B Tefera, and S Bekele(eds) prociding of the 16th international comference of Ethiopian studies (PP1033-1044), Trandihim: Norway. 2009.

[15]. YITBARIK S. PROBLMS AND SURVIVAL STRATEGIES OF FEMALE STREET CHILDREN IN ADDIS ABABA: St. Mary's University; 2012.

[16]. Uddin MJ, Sarma H, Wahed T, Ali MW, Koehlmoos TP, Nahar Q, et al. Vulnerability of Bangladeshi street-children to HIV/AIDS: a qualitative study. BMC public health. 2014;14(1):1-

[17]. Tetteh W. The Phenomenon of Children Beggars on the Streets of Accra: University of Ghana; 2018. 
[18]. Black M, editor. Street and Working Children: Global Seminar Report, 1993. Innocenti Global Seminar Papers; 1993.

[19]. Tipple G, Speak S. Who is homeless in developing countries?: Differentiating between inadequately housed and homeless people. International Development Planning Review. 2006;28(1).

[20]. Unicef. Orphans and other vulnerable children and adolescents in Zimbabwe. Zimbabwe: UNICEF. 2001.

[21]. Volpi E. Street children: Promising practices and approaches. 2002.

[22]. Deo K. Substance Abuse Among Street Children In Mumbai 2016.

[23]. Heinonen P. Youth gangs and street children: culture, nurture and masculinity in Ethiopia: Berghahn Books; 2011.

[24]. Basnet P. The lost childhood of street children in Nepal: Wichita State University; 2010.

[25]. Organization WH. Working with street children: a training package on substance abuse, sexual and reproductive health including HIV/AIDS and STDs. World Health Organization, 2000.

[26]. Chauke TA, Mudau TJ. "Why am I here and what does South Africa new dawn mean for me?" Youth streetism in the City of Polokwane. Journal of Gender, Information and Development in Africa (JGIDA). 2019;8(Special Issue 2):181-93.

[27]. Chetty VR. Street Children in Durban: An Exploratory Investigation: ERIC; 1997.

[28]. Jenson JM, Fraser MW. A risk and resilience framework for child, youth, and family policy. Social Policy for Children and Families: A Risk and Resilience Perspective. 2015.

[29]. Kipyegon K, Nyarombe Nyachwaya F, Achimba Okirigiti C, Kamar Kipchirchir I. Factors influencing rising number of street children in urban centers in Kenya: a survey of Eldoret Municipality, Kenya. 2015.

[30]. Organization WH. The world health report 2002: reducing risks, promoting healthy life: World Health Organization; 2002.

[31]. Kebede SK. The situation of street children in urban centers of Ethiopia and the role of NGO in addressing their socio-economic problems: the case of Hawassa City. Int J Acad Res Educ Rev. 2015;3(3):45-57.

[32]. Awatey S. Assessing the effects of streetism on the livelihood of street children: A case study of Kumasi (in Ghana). Research on humanities and social sciences. 2014;4(9):165-74.

[33]. Van Blerk L. Berg-en-See street boys: merging street and family relations in Cape Town, South Africa. Children's geographies. 2012;10(3):321-36.

[34]. Kiros A. Onset, experiences, and termination of streetism: an ethnographic case study on street children in the city of Mekelle, Ethopia. Imperial journal of interdisciplinary research (IJIR). 2016;2(2). 
[35]. C. Population and Housing Census of Ethiopia 2007: Statistical Report. Federal Democratic Republic of Ethiopia Addis Ababa, Ethiopia; 2007.

[36]. Marczyk G, DeMatteo D. Essentials of research design and methodology: John Wiley \& Sons; 2005.

[37]. Bryman A. Social research methods: Oxford university press; 2016.

[38]. Brooks JE. Strengthening resilience in children and youths: Maximizing opportunities through the schools. Children \& Schools. 2006;28(2):69-76.

[39]. Tuladhar P. Situation and Causes of Street Children (A Sociological Study of Kathmandu Valley): Central Department of Sociology and Anthropology Tribhuvan University ...; 2013.

[40]. Radford L. A review of international survey methodology on child sexual abuse and child sexual exploitation. 2018.

[41]. Adugna G. Livelihoods and survival strategies among migrant children i Addis Ababa: Geografisk institutt; 2006. 


\section{DECLARATION}

This thesis is my original work atWollo University, institute of teachers' education and behavioral sciences department of psychology. This work has not been presented for adegree in any other university and that all sources of material used for the thesis have been dulyacknowledged.

Name: Moges Gebresellassie 


\section{APPENDIX ONE}

\section{WOLLO UNIVERSITY}

\section{INSTITUTION TEACHERS EDUCATION AND BEHAVIORAL SCIENCE DEPARTMENT OF PSYCHOLOGY}

\section{QUESTIONNAIRE PREPARED TO ASSESSTHE CAUSES, PREVALANCE AND PSYCHO SOCIAL WELLBEING OF STREET CHILDREN}

\section{Dear participants:}

This questionnaire is aimed gathering relevant data in order to investigate the causes, prevalence and psychological wellbeing of street children in Dessie town piyassa, Arada and Menaharia the requirement of the partial fulfillment of BA degree in psychology. The questionnaire helps to know the cause, prevalence and psychology wellbeing of street children. Your genuine response is vital for the success and reliability of the study. The researcher wants to assure you that your responses was be treated with confidentiality and only used for the sake of this study.

Thank you for your cooperation

\section{Part one}

Background information (please writes on space or circle an alternative as appropriate)

1) Age: A. below 10 years B. 11-15 years C. 16-20 years

2) Sex: A. Male $\quad$ B. Female

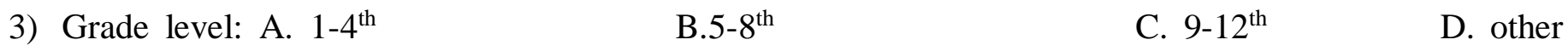
(specify)....................
4) Religion:
A. orthodox
B. catholic
C. protestant
D. other (specify).

5) Place of birth: A. Rural B. urban

\section{Section one - causes of street life}

Listed below are statements that represent possible causes for being on street. With respect to your own current life, please indicate the degree of agreement or disagreement with each statement by making one of the five alternatives after each statement. 
Criteria, $\quad 1=$ strongly disagree $2=$ disagree $3=$ neutral $4=$ agree $5=$ strongly agree

\begin{tabular}{|l|l|l|l|l|l|l|}
\hline \multirow{2}{*}{ No } & Items forwarded & \multicolumn{4}{|l|}{ Level } \\
& & \multicolumn{4}{|l|}{ Agreement } \\
\hline 1 & The presence of strict parenting makes me to be a street child & 1 & 2 & 3 & 4 & 5 \\
\hline 2 & There quarrel at our home leads me to become street child & 1 & 2 & 3 & 4 & 5 \\
\hline 3 & The low level of feeding pattern makes me to be a street child & 1 & 2 & 3 & 4 & 5 \\
\hline 4 & My families economy is not enough to serve us & 1 & 2 & 3 & 4 & 5 \\
\hline 5 & Since 1 have scored low at school I become hopeless and I prefer street life & 1 & 2 & 3 & 4 & 5 \\
\hline 6 & I have no work to lead my life that I prefer street life & 1 & 2 & 3 & 4 & 5 \\
\hline 7 & Peer pressure triggers me to become street child & 1 & 2 & 3 & 4 & 5 \\
\hline 8 & being and orphaned influences me to become street child & 1 & 2 & 3 & 4 & 5 \\
\hline
\end{tabular}

\section{Section two -prevalence of street life}

Listed below are statements that represent possible prevalence of Street life .With respect to your mu: $\mathrm{cu}$ life, please indicate the degree of your agreement or disagreement with each statement by marking one of the five alternatives after each statement.

Criteria, $1=$ strongly disagree, $-=$ disagree, $a=$ neutral $4=$ agree, $5=$ strongly agree

\begin{tabular}{|c|c|c|c|c|c|c|}
\hline No & Items forwarded & \multicolumn{5}{|c|}{ Level of Agreement } \\
\hline 1 & After I have joined street life, many other children are also include & 1 & 2 & 3 & 4 & 5 \\
\hline 2 & Interventions are made to minimize the rate of street life. & 1 & 2 & 3 & 4 & 5 \\
\hline 3 & Awareness creation is implemented to combat causes of street life. & 1 & 2 & 3 & 4 & 5 \\
\hline
\end{tabular}

\section{Section three -psychosocial wellbeing}

Listed below are statements that represent possible impact of street life on psychological wellbeing. With respect to your own current life, please indicate the degree of your agreement or disagreement with each statement by marking one of the five alternatives after each statement.

The scales represent: I=strongly disagree, 2: disagree, 3: neutral 4agree, 5 strongly agree 


\begin{tabular}{|c|c|c|c|c|c|c|}
\hline \multirow{2}{*}{ No } & Items forwarded & \multicolumn{4}{|c|}{ Level of frequency } \\
\hline 1 & I have encountered experience of sexual abuse. & 1 & 2 & 3 & 4 & 5 \\
\hline 2 & I have encountered experience of physical abuse. & 1 & 2 & 3 & 4 & 5 \\
\hline 3 & I am exposed to drug addiction. & 1 & 2 & 3 & 4 & 5 \\
\hline 4 & I have stopped attending school. & 1 & 2 & 3 & 4 & 5 \\
\hline 5 & Street life exposed me to sever injury. & 1 & 2 & 3 & 4 & 5 \\
\hline 6 & Street life exposed me to psychological disturbances. & 1 & 2 & 3 & 4 & 5 \\
\hline 7 & Street life exposed me to social exclusion. & 1 & 2 & 3 & 4 & 5 \\
\hline
\end{tabular}

Thanks for your cooperation!!! 